\title{
開閉インパルス電圧波形パラメータの計算法
}

\begin{tabular}{|c|c|c|c|c|c|c|c|}
\hline 正員 & 里 & 周二 & (宇都宮大学) & 学生貝 & 伊藤 & 智章 & (宇都宮大学) \\
\hline 正員 & 原田 & 達哉 & (日本工業大学) & 正貝 & 脇本 & 隆之 & (日本工業大学) \\
\hline 正員 & 传伯 & 正盛 & (日本工業大学) & & & & \\
\hline
\end{tabular}

\section{A Study on Impulse Parameter Estimation for Switching Impulse Voltage}

SATO Shuji: Member, ITO Tomoaki: Student Member (Utsunomiya University),

HARADA Tatsuya: Member, WAKIMOTO Takayuki: Member and SAEKI Masamori: Member (Nippon Institute of Technology)

Approximation functions, which determine the switching impulse voltage parameters using the definition for the lightning impulse, are proposed. The paper demonstrates any waveform defined as a switching impulse voltage by the IEC can precisely be processed with negligibly small error. The details of the approximation technique are also discussed in the paper.

キーワード: 開閉インパルス電圧パラメータ, 雷インパルス電圧波形, 函数近似

\section{1. まえがき}

開閉インパルス電圧波形は雷インパルス電圧波形と異な り, 波形の絶対原点を起点としてピーク值までの時間を $\mathrm{T}_{\mathrm{p}}$ $(\mu \mathrm{sec})$, ピーク值の50\%に減衰するまでの時閒を $\mathrm{T}_{2}(\mu \mathrm{sec})$ を 用いて， $T_{p} / T_{2}$ impulseと記述することがIEC60060-2で定め られている。この定義に従うと波形パラメータに大きな不 確かさを伴うことが知られており, 雷インパルス方式の定 義から開閉インパルス方式一の変換法が提案されているり。 今回等者らは，従来の変換方式では記述できなかった急峻 な領域の波形も精度良く変換できる近似式を開発したので 詳細を報告する。

\section{2. 開閉インパルス電圧波形定䑾の問題点}

IEC の定める定義方法に従って開閉インパルス電圧の波 形パラメータ $\mathrm{T}_{\mathrm{p}}, \mathrm{T}_{2}$ を定める場合に指摘されている問題点 は,ピーク值に至る時刻 $\mathrm{T}_{\mathrm{p}}$ を決定する過程にある。IEC の 定める 2)開閉インパルス電圧の最短の波頭長は $20 \mu \mathrm{sec}$ であるが，例えば 20/4000impulseの波形がピーク値の 9 9.9\%(ほほ 10bit 分解能のデジタル計測器の量子化誤差

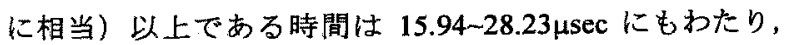
真值 $20 \mu \mathrm{sec}$ に比べ $61.4 \%$ も誤差が存在する。また, 標淮 開閉インパルス (250/2500impulse) でも同様な誤差は $15.9 \%$ にもなり,やはり $\mathrm{T}_{\mathrm{p}}$ 精度良く決定することは難しい。

これまでアナログ測定器を使用する場合には重要ではな かったが, デジタル測定器で記録されたデータの絶対原点 の決定法は困難な問題である。不正確な絶対原点を用いて $\mathrm{T}_{\mathrm{p}}, \mathrm{T}_{2}$ を決定することは必然的に波形パラメータに無視でき ない不確かさの介在する余地を残すことになる。

この問題を解消する方法は, 雷インパルス電压の定義に 従うことであるが，そのような定義はまだ IEC 規格には盛 り込まれていないので, 以下に雷インパルス電圧の波形パ ラメータ $\mathrm{T}_{1 \mathrm{~L}}, \mathrm{~T}_{2 \mathrm{~L}}$ から $\mathrm{T}_{\mathrm{p}}, \mathrm{T}_{2}$ を決定するアルゴリズムにつ いて説明する。

\section{3. 雷インパルス電圧波形パラメータ}

図 1 は, 雷インパルス電圧波形を記述する 2 重指数函数 $\exp (-\alpha \mathrm{t})-\exp (-\beta \mathrm{t})$ の波形パラメータの定義を示したものである。

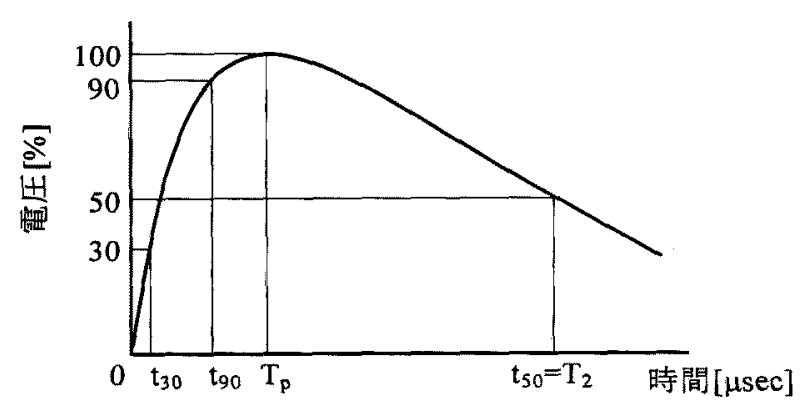

图 1 雷インパルス電圧波形パラメータ

Fig. 1 Impulse voltage parameters definitions

もし, $\mathrm{T}_{\mathrm{p}}, \mathrm{T}_{2}$ を $\mathrm{T}_{1 \mathrm{~L}}$ と $\mathrm{T}_{2 \mathrm{~L}}$ の 2 つのパラメータの函数よ して,

$$
T_{p}=T_{p}\left(T_{1 L}, T_{2 L}\right), \quad T_{2}=T_{2}\left(T_{1 L}, T_{2 L}\right)
$$

と記述することが可能なら, 㮸来通りの雷インパルス電圧 波形パラメータ決定アルゴリズムにより $\mathrm{T}_{1 \mathrm{~L}}, \mathrm{~T}_{2 \mathrm{~L}}$ を求め, これらから簡単に $\mathrm{T}_{\mathrm{p}}, \mathrm{T}_{2}$ を決定することが可能となる。

この計算に入る前に次の事実を確認しておこう。 $\exp (-\alpha \mathrm{t})-\exp (-\beta \mathrm{t})$ と時間軸方向に規格化した $\exp (-\mathrm{t})-\exp (-\mathrm{kt})$ は時間方向に $\alpha$ 倍だけ尺度が異なるので,これらの波形から 得られる波形パラメータもやはり 関するパラメータ間の比（例えば $\mathrm{T}_{2} / \mathrm{T}_{\mathrm{p}}$ や $\mathrm{T}_{2 \mathrm{~L}} / \mathrm{T}_{1 \mathrm{~L}}$ など）は

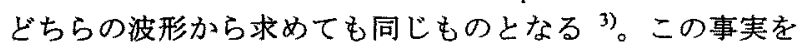
ふまえ, 筆者らは exp(-t)-exp(-kt) の k を変化させ, 各波形 から Newton 法により雷インパルス波形パラメータ（図 1 参照） $t_{30}, t_{90}, t_{50}$ を求め, さらに規約原点 $t_{0} と T_{1 L}, T_{2 L}$, 老,

$$
\begin{aligned}
t_{0} & =1.5 t_{30}-0.5 t_{90} \\
T_{1 L} & =\left(t_{90}-t_{30}\right) / 0.6, \quad T_{2 L}=t_{50}-t_{0}
\end{aligned}
$$


と計算した。一方， $T_{\mathrm{p}}$ は 2 重指数函数から解析的に計算可 能であり， $\mathrm{T}_{2}$ は $\mathrm{t}_{50}$ に他ならないことは明らかであろう。

\section{4. 雷インパルス電圧波形パラメータと開閉インパル} ス電圧波形パラメータ

前節で述べた手続きに従って得られた $T_{1 L}, T_{2 L}, T_{p}, T_{2}$ を種々の $\mathrm{k}$ の值について求め, 横軸を $\mathrm{T}_{2 \mathrm{~L}} / \mathrm{T}_{1 \mathrm{~L}}$ にとり, 粕軸 を $\mathrm{T}_{\mathrm{p}} / \mathrm{T}_{1 \mathrm{~L}}$ 及び $\mathrm{T}_{2} / \mathrm{T}_{1 \mathrm{~L}}$ と無次元化したグラフに描くことによ り， $T_{1 L} ， T_{2 L}$ が既知であれば $T_{p}, T_{2}$ を読み取ることは可能 である ${ }^{4)}$ 。しかし，グラフの読み取りには個人差があり， また，小さなグラフから読み取られた数值は誤差の入り込 む余地が大きい。

\section{5. 近似函数}

グラフの読み取り誤差の問題を解決するため以下に近似 函数を提案する。

描かれた $\mathrm{T}_{\mathrm{p}} / \mathrm{T}_{1 \mathrm{~L}}$ 及び $\mathrm{T}_{2} / \mathrm{T}_{1 \mathrm{~L}}$ のグラフの $\mathrm{T}_{2 \mathrm{~L}} / \mathrm{T}_{1 \mathrm{~L}} \approx 3.4700$ 近傍（非振動隇衰開閉インパルスは常にこの值が 3.4700 よ り大きい。）及び $\mathrm{T}_{2 \mathrm{~L}} / \mathrm{T}_{1 \mathrm{~L}}$ が極めて大きな場所での函数の振 る舞いから漸近曲線を求め, 2 つの漸近曲線を滑らかに結ぶ 近似函数を仮定し，近似函数の不定パラメータを最小 2 乗 法及び重みフィルター法 ${ }^{3)} よ り$ 最適化した。最終的に得 られた近似式は次の 2 つである。但し， $\mathrm{x}=\mathrm{T}_{2 \mathrm{~L}} / \mathrm{T}_{1 \mathrm{~L}}-3.4700$ と定義する。なお，(5) 式中， $a_{1}$ が 2 度現れているのは誤植 ではない。

$$
\begin{aligned}
T_{p} / T_{1 L} & =a_{1} x /\left(1+a_{2} x^{0.9}+a_{3} x^{0.8}+a_{4} x^{0.7}+a_{5} x^{0.6}\right) \\
& +a_{6} \\
a_{1} & =0.052667, a_{2}=0.14171, a_{3}=-0.46697 \\
a_{4} & =0.78714, a_{5}=-0.24746, a_{6}=1.2415 \\
T_{2} / T_{2 L} & =x-a_{1}+a_{1} /\left(1+a_{2} x^{a_{3}}\right)+a_{4} \\
a_{1} & =0.044888, a_{2}=0.28339, a_{3}=0.88181 \\
a_{4} & =3.3253
\end{aligned}
$$

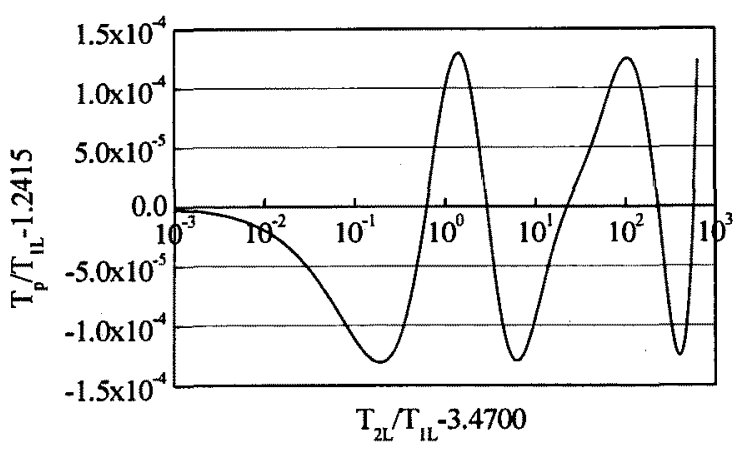

图 2 (4) 式の犃差分布

Fig. 2 Error distribution using eqn.(4)
図 2，3 は (4)，(5) 式で与えられる近似函数の誤差分布を 描いたものである。いずれの場合も「誤差の符号が交互に 反転し，かつ最大誤差の大きさがほぼ等しい」という，ミ ニマックス条件を満たす最適函数であることが判る。

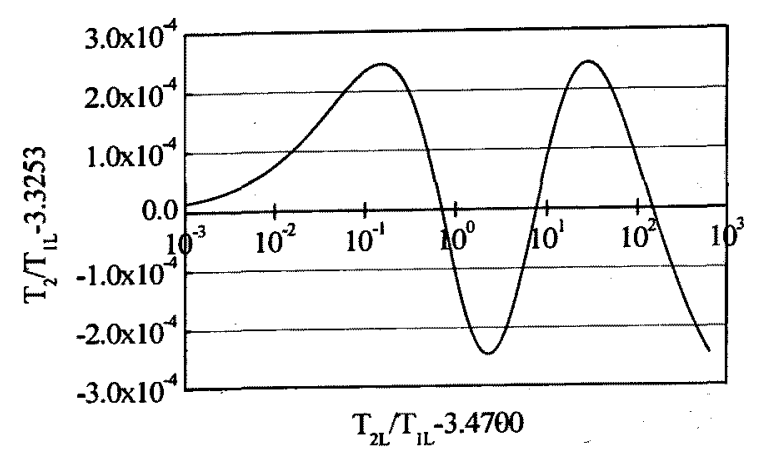

图 3 (5) 式の請差分布

Fig. 3 Error distribution using eqn.(5)

\section{6. 近似函数の評価}

前節で紹介した近似函数を実際の開閉インパルスに適用 してその誤差を評価してみよう。最も急峻な 20/4000impulse を与える 2 重指数函数の波形に (4), (5) 式を適用したとこ ろ，20.0003/4000.0017impulse となり，誤差は 0.0015\%とな った。また最も緩慢な 300/1000impulse の場合においても， 299.978/1000.02impulse となり，誤差は 0.0072\%と，やはり 極めて小さいことが確認できる。

\section{7. まとめ}

開閉インパルス電圧波形パラメータを雷インパルス電圧 波形パラメータの定義から変換する近似式を提案し，広範 囲の波形に対し，精度良い近似式であることを確憶した。

(平成 13 年 4 月 16 日受付, 平成 13 年 6 月 5 日再受付)

\section{参考文献}

1) 脇本 隆之, 里 周二, 原田 達哉, 佐伯 正盛:「開閉 インパルス電圧の高精度波頭長算出法の提案」, 電気 学会論文誌 B, Vol.118-B, No.5, pp.548-554, 1999

2) IEC 61083-1 "Digital recorders for measurements in high-voltage impulse tests", 1991

3）里 周二, 加藤 巧二, 伊藤 智章, 坂口 寿美子 : 「雷 インパルス 2 重指数函数パラメータの計算法」, 電気 学会論文誌 A, Vol.120-A, No.11, pp.1000-1006, 2000

4) 里 周二, 加藤巧二, 伊藤 智章, 原田 達哉, 脇本 隆 之, 佐伯 正盛: 「開閉インパルス電圧波形パラメータ の計算法」, 平成 12 年電気学会電力・エネルギー部門 大会論文集 B, No.548,pp.459-460,2000 年 8 月 